\title{
Analisis Empat Dimensi Kebijakan Izin Usaha Pengelolaan dan Pengusahaan Sarang Burung Walet di Kota Pekanbaru Provinsi Riau
}

\author{
Rinaldy May ${ }^{1}$, Tri Yuniningsih ${ }^{2}$, Endang Larasati ${ }^{3}$ \\ 1,2,3,Departemen Administrasi Publik, Fakultas Ilmu Sosial dan Ilmu Politik. Universitas \\ Diponegoro, Semarang \\ Jalan Professor Soedarto SH, Tembalang, Kec. Tembalang, Kota Semarang, Jawa Tengah
} 50139

\begin{abstract}
Pekanbaru City Regulation Number 3 of 2007 concerning Business Permits for Management and Exploitation of Swallow's Nests aims to preserve the environmental sustainability of the management and exploitation of swallow's nest. The problems that arise include the very minimal number of business permits that impact the contribution of regional income, noise pollution, air pollution, environmental impacts, and health problems. The purpose of this study is to analyze the management and management of swallow nests in Pekanbaru City. The approach uses descriptive qualitative data techniques that combine interviews, documentation, and observation. From the research, it can be seen that the policy of managing and exploiting swallow's nest has not been effective. Communication with target groups is carried out through socialization, but it is not practical. The quantity of human resources is still limited. The budget for the operation of the swallow's nest business license is still not optimal. Facilities are also still not optimal. Policy policies seen from the commitment of policy implementers tend to be lacking. Coordination in the supervisory process is not carried out consistently. Supporting factors are the assumptions of explicit policy assumptions and realities, authority resources, social and political conditions, and community support. The inhibiting factor is the information that forms policy formulation, apparatus resources, budget, facilities; economic needs; and target group support.
\end{abstract}

Keywords: business license, swallow's the nest, policy implementation

\section{Pendahuluan}

Data dari Dinas Penanaman Modal dan Pelayanan Terpadu Satu Pintu (DPMPTSP) Kota Pekanbaru menunjukkan bahwa sebagian besar usaha sarang burung walet yang ada di Kota Pekanbaru belum memiliki izin. Bahkan ada di salah satu kecamatan dimana tidak ada satu pun usaha sarang burung walet yang memiliki izin. Tentu hal ini sangat miris karena jika melihat di lapangan banyak sekali usaha sarang burung walet di Kota Pekanbaru, bahkan lokasinya dekat dengan permukiman masyarakat. Menurut Dinas 
Penanaman Modal dan Pelayanan Terpadu Satu Pintu (DPMPTSP) Kota Pekanbaru tahun 2019, sampai saat ini sekitar 59 penangkaran sarang burung walet yang memiliki izin seperti yang dapat dilihat pada tabel 1. di bawah ini.

Tabel 1.

Jumlah Izin Sarang Burung Walet di Kota Pekanbaru

\begin{tabular}{|c|l|r|r|r|r|r|}
\hline \multirow{2}{*}{ No } & \multicolumn{1}{|c|}{ Kecamatan } & \multicolumn{2}{c|}{$\begin{array}{l}\text { Usaha yang } \\
\text { Memiliki Izin }\end{array}$} & \multicolumn{2}{|c|}{$\begin{array}{c}\text { Usaha yang Tidak } \\
\text { Memiliki Izin }\end{array}$} & Jumlah \\
\hline 1 & Tampan & 2 & $13,3 \%$ & 13 & $86,7 \%$ & 15 \\
\hline 2 & Bukit Raya & 1 & $2,9 \%$ & 34 & $97,1 \%$ & 35 \\
\hline 3 & Payung Sekaki & 6 & $50 \%$ & 6 & $50 \%$ & 12 \\
\hline 4 & Senapelan & 12 & $34,3 \%$ & 23 & $65,7 \%$ & 35 \\
\hline 5 & Rumbai Pesisir & 1 & $33,3 \%$ & 2 & $66,7 \%$ & 3 \\
\hline 6 & Rumbai & 6 & $100 \%$ & 0 & $0 \%$ & 6 \\
\hline 7 & Tenaran Raya & 7 & $6,9 \%$ & 94 & $93,1 \%$ & 101 \\
\hline 8 & Sail & 12 & $92,3 \%$ & 1 & $7,7 \%$ & 13 \\
\hline 9 & Pekanbaru Kota & 0 & $0 \%$ & 2 & $100 \%$ & 2 \\
\hline 10 & Limapuluh & 11 & $7,1 \%$ & 145 & $92,9 \%$ & 156 \\
\hline 11 & Sukajadi & 1 & $1,6 \%$ & 63 & $98,4 \%$ & 64 \\
\hline 12 & Marpoyan Damai & 0 & $0 \%$ & 56 & $100 \%$ & 56 \\
\hline \multicolumn{2}{|c|}{ Total Jumlah } & 59 & $11,8 \%$ & 439 & $88,2 \%$ & 498 \\
\hline
\end{tabular}

Sumber : DPMPTSP Kota Pekanbaru (2019)

Walaupun regulasi yang mengatur pengusahaan sarang burung walet telah diterbitkan oleh Pemerintah Kota Pekanbaru, namun saat ini usaha budidaya sarang burung walet di Kota Pekanbaru sangat meresahkan warga, apalagi jika letaknya di tengah Kota Pekanbaru dan berdekatan dengan pemukiman warga. Bunyi keras dari kaset rekaman burung walet terdengar hingga ke pemukiman masyarakat sehingga sangat mengganggu kenyamanan, apalagi ditambah dengan resiko pencemaran lingkungan yang berakibat pada timbulnya beberapa penyakit yang bisa mengganggu kesehatan manusia (https://riaupos.jawapos.com/pekan baru/19/01/2014/41407/pekandepan-dprd-panggil-tim-terpadusarang-walet.html).

Penelitian terdahulu yang telah dilakukan Hayati (2018:11) dapat diketahui dalam rangka memberikan perlindungan hukum untuk warganya, Pemerintah Kota Palangkaraya menerbitkan kebijakan sebagai petunjuk pelaksana pengelolaan dan pengusahaan sarang burung walet serta prosedur pengaduan dan penanganan aduan masyarakat mengenai dugaan pencemaran atau perusakan lingkungan yang diakibatkan oleh kegiatan usaha sarang burung walet dimaksud. Hal ini untuk menyelesaikan permasalahan karena pengembangan budidaya sarang burung walet yang berdampak pada pencemaran lingkungan dan gangguan kesehatan masyarakat. Penelitian lain dilakukan oleh Susilowati (2018:13) yang menemukan hambatan dalam implementasi kebijakan di Kota Palangkaraya mengenai izin pembangunan gedung usaha sarang 
burung walet. Kebijakan dimaksud masih kurang disosialisasikan untuk kelompok sasaran, ditambah peran serta dari masyarakat untuk mengawasi serta pengawasan oleh pemerintah masih sangat kurang untuk pembangunan gedung usaha sarang burung walet di Kota Palangkaraya yang diduga melanggar aturan.Kemudian Yuan (2017:15) mengungkapkan persepsi sebagian besar masyarakat mengenai lokasi usaha sarang burung walet di Kelurahan Temindung Permai Kecamatan Sungai Pinang Kota Samarinda merasa terganggu karena lokasi usaha yang berada di tengah pemukiman warga. Kekhawatiran tersebut timbul karena struktur bangunan usaha sarang burung walet yang tinggi, sedangkan pondasi bangunannya sejak awal tidak ditujukan untuk bangunan bertingkat sehingga rentan untuk runtuh. Selain itu, masyarakat juga terganggu karena gangguan suara oleh rekaman pemanggil burung walet, resiko penularan penyakit, serta radiasi suara yang berefek samping beberapa tahun kemudian. Penelitian Rizki Chandra( 2024) diketahui bahwa Pelaksanaan Koordinasi Penertiban Usaha Pengelolaan Dan Pengusahaan Sarang Burung Walet Di Kota Pekanbaru, Pelaksanaan koordinasi dalam penertiban usaha pengelolaan dan pengusahaan sarang burung walet di Kota Pekanbaru belum maksimal.Faktor-faktor yang mempengaruhi pelaksanaan koordinasi penertiban usaha pengelolaan dan pengusahaan sarang burung walet Di Kota Pekanbaru adalah waktu penertiban dan anggaran biaya. Peneliyian Bherry Tinanto (2015) dengan judul Pelaksanaan Kebijakan Pajak Sarang Burung Walet Kota Pekanbaru Tahun $\begin{array}{lrr}\text { 2012-2013 } & \text { Dalam } & \begin{array}{r}\text { Perspektif } \\ \text { Otonomi }\end{array} \\ \text { Daerah, } & \text { temuan }\end{array}$ penelitiannya adalah Pemaerintah Kota Pekanbaru tidak serius dalam pelaksanaan kebijakan pajak sarang burung walet 2012-2013, karena implementor tidak melakukan komunikasi kepada target, tidak dilakukan pengawasan dan pendataan bahkan pemberian sanksi. Hambatan yang dihadapi adalah wajib pajak yang tidak berdomisili di kota Pekanbaru sehingga menyulitkan dalam komunikasi dan anggaran yang minim. Rio Mardian Saputra(2015) tentang Pengawasan Terhadap Penangkaran Sarang Burung Walet Di Kota Pekanbaru, dimana temuannya adalah Pengawasan khusus yang dilakukan oleh tim pengawas penangkaran sarang burung walet di Kota Pekanbaru belum maksimal dikarenakan beberapa faktor-faktor : kurangnya APBD, kurangnya personil, terbatasnya sarana dan prasarana, kurangnya koordinasi. Dari beberapa penelitian sebelumnya memperlihatkan bahwa sangat dibutuhkan kebijakan yang mengatur mengenai pengusahaan sarang burung wallet selain itu kebaruan penelitian ini adalah mengkaji kebijakan dari dimesi mplementasi.Masalah penelitian ini adalah implementasi kebijakan izin pengelolaan dan pengusahaan sarang burung walet di Kota Pekanbaru yang belum efektif. Kebijakan yang dibutuhkan tidak hanya mengenai tujuan, persyaratan serta sanksi yang tercantum dalam peraturan tersebut. Pelaksanaan kebijakan membutuhkan dukungan dari kualitas pelaksana kebijakan yang akan menjadi ujung tombak keberhasilan, dan juga masyarakat sebagai pihak yang merasakan 
dampak dari pelaksanaan kebijakan tersebut.Berdasarkan latar belakang di atas maka pertanyaan penelitian yang akan dijawab adalah mengapa implementasi kebijakan izin pengelolaan dan pengusahaan sarang burung walet di Kota Pekanbaru belum maksimal.

\section{Metode Penelitian}

Penelitian ini menggunakan pendekatan kualitatif bertipe deskriptif. Pemilihan lokus penelitian dengan pertimbangan masih banyaknya pengusaha burung wallet yang belum memiliki izin usaha. Data yang digunakan dalam penelitian ini adalah data primer (data bersumber dari informan) dan data sekunder (buku pustaka, catatan ilmiah, jurnal dan artikel ilmiah serta laporan, arsip ataupun dokumen lainnya). Informan ditentukan dengan menggunakan teknik purposive Data lapangan dikumpulkan melalui cara wawancara langsung, daring dan/atau telepon, dokumentasi serta observasi. Analisis data dengan tahapan mengolah data, mengorganisasi data, mengklasifikasikannya, menyusunnya, mencari dan menemukan pola, serta memutuskan apa yang akan disampaikan kepada orang lain (dalam Moleong, 2007). Triangulasi data digunakan dalam rangka validitas data.

\section{Hasil dan Pembahasan}

\section{Implementasi Kebijakan Izin Pengelolaan dan Pengusahaan Sarang Burung Walet di Kota Pekanbaru}

Kebijakan izin usaha pengelolaan dan pengusahaan sarang burung walet di Kota Pekanbaru diatur dalam Peraturan Daerah Kota
Pekanbaru Nomor 3 Tahun 2007 Tentang Izin Usaha Pengelolaan Dan Pengusahaan Sarang Burung Walet. Dalam Perda tersebut disebutkan bahwa permohonan izin diterima dan dilakukan pencatatan secara administratif oleh Dinas Peternakan, untuk kemudian dilaksanakan penelitian di lokasi secara koordinatif serta pembahasan oleh Tim Penilai. Tim Penilai terdiri dari Dinas Tata Kota, Dinas Kesehatan Kota, Dinas Pendapatan Daerah, Bapedalda, Dinas Peternakan, Bagian Perekonomian Pemerintah Kota, serta Dinas, Badan, Kantor dan bagian terkait lainnya. Perda tersebut didukung oleh peraturan teknis berupa Peraturan Walikota Pekanbaru Nomor 2 Tahun 2009 Tentang Petunjuk Pelaksanaan dan Petunjuk Teknis Peraturan Daerah Nomor 3 Tahun 2007 Tentang Izin Usaha Pengelolaan Dan Pengusahaan Sarang Burung Walet dan Peraturan Daerah Nomor 7 Tahun 2007 Tentang Retribusi Izin Pengelolaan Dan Pengusahaan Sarang Burung Walet.

Implementasi kebijakan izin usaha pengelolaan dan pengusahaan sarang burung walet di Kota Pekanbaru belum berjalan secara efektif. Pada Peraturan Daerah Kota Pekanbaru Nomor 3 Tahun 2007 pasal 2 ayat (1) disebutkan bahwa "Objek izin usaha pengelolaan dan pengusahaan sarang burung walet adalah semua lokasi usaha di wilayah kota yang kegiatannya diperuntukkan untuk mengelola dan mengusahakan sarang burung walet", pasal 3 berbunyi "Subjek izin usaha pengelolaan sarang burung walet adalah setiap orang atau badan hukum yang kegiatannya mengelola dan mengusahakan sarang burung walet", dan pasal 6 ayat (1) berbunyi "Setiap orang atau badan yang 
mengelola dan mengusahakan sarang burung walet harus mempunyai izin dari Walikota." Dari pasal tersebut dapat diketahui bahwa kebijakan izin usaha dimaksud ditujukan untuk seluruh usaha sarang burung walet yang ada di Kota Pekanbaru. Namun pada proses implementasinya, belum semua usaha sarang burung walet di Pekanbaru yang memiliki izin usaha, Jumlah usaha sarang burung walet di Pekanbaru yang memiliki izin usaha hanya sekitar 11,8\%, bahkan seluruh usaha sarang burung walet yang ada di kecamatan Marpoyan Damai tidak memiliki izin usaha. Padahal dalam Perda dimaksud tercantum dengan jelas bahwa seluruh usaha sarang burung walet di Kota Pekanbaru diwajibkan memiliki izin usaha.

Implementasi kebijakan izin usaha pengelolaan dan pengusahaan sarang burung walet di Pekanbaru juga dinilai tidak efektif karena banyak pengusahaan sarang burung walet di Pekanbaru dilakukan di rumah toko (ruko) yang berada di depan jalan raya dan berdekatan dengan pemukiman masyarakat. Padahal jika dilihat dari isi kebijakan yang tercantum pada bab III pasal 4 ayat (3) yang berbunyi, "Sarang burung walet yang berada diluar habitat alami meliputi: a. Pada bangunan b. Pada Rumah/Gedung tertentu", menunjukkan bahwa usaha sarang burung walet harus dilakukan di bangunan khusus dengan kriteria tertentu. Penggunaan gedung yang tidak sesuai dengan kriteria di Perda akan menimbulkan persoalan tersendiri, karena hal ini ditujukan untuk melindungi kenyamanan masyarakat mengingat lokasi sebagian besar ruko berada di tengah kegiatan masayarakat. Dalam proses untuk mendapatkan izin usaha sarang burung walet, pengusaha sarang burung walet harus memenuhi persyaratan yang tercantum dalam pasal 6 ayat (2) yang berbunyi "Untuk mendapatkan izin pengelolaan dan pengusahaan sarang burung walet sebagaimana dimaksud pada ayat (1) harus mengajukan permohonan tertulis kepada Walikota melalui Dinas Peternakan dengan melampirkan : a. Identitas Pemohon; b. Luas areal pemanfaatan; c. Pernyataan tidak keberatan dari tetangga kiri, kanan, muka dan belakang dilokasi tempat kegiatan usaha yang dimohonkan, yang diketahui oleh Lurah dan Camat setempat; d. Gambar situasi lokasi tempat usaha yang diperuntukkan khusus untuk penangkaran sarang burung walet dengan jarak sekurangkurangnya 100 (seratus) meter dari pemukiman penduduk dan menyebutkan pula fungsi bangunan tersebut; e. Uraian singkat rencana kegiatan pengusahaan dan pengelolaan sarang burung walet; $f$. Peta lokasi yang menunjukkan batasbatas titik koordinat secara jelas dengan skala 1:1000; g. Status tanah/lokasi pengusahaan dan pengelolaan sarang burung walet; $h$. Nomor Pokok Wajib Pajak Daerah (NPWPD); i. Akte pendirian bagi perusahaan yang berbadan hukum; $j$. Tanda pelunasan pembayaran Pajak Bumi dan Bangunan (PBB) tahun terakhir; k. Untuk permohonan perpanjangan usaha pengusahaan dan pengelolaan sarang burung walet harus melampirkan tanda pelunasan pembayaran pajak pengelolaan dan pengusahaan sarang burung walet; $l$. Surat pernyataan bahwa pemohon akan mempekerjakan masyarakat setempay yang diketahui oleh Lurah; m. Surat pernyataan bahwa yang bersangkutan dalam mengelola dan megusahakan sarang burung walet 
akan mentaati semua persyaratan teknis terutama dampak lingkungan sesuai dengan ketentuan yang berlaku; n. Khusus untuk pengolalaan dan pengusahaan sarang burung walet diluar habitat alami harus dilengkapi dengan Izin Gangguan dan Izin Mendirikan Bangunan (IMB)." Namun pada implementasinya, lokasi usaha sarang burung walet yang sebagian besar berdekatan dengan pemukiman masyarakat menjadi salah satu kendala pengusaha sarang burung walet untuk mengurus izin usaha sarang burung walet karena pada persyaratan izin usaha sarang burung walet yang tercantum pada pasal 6 ayat (2) huruf d terdapat kewajiban memenuhi jarak minimal usaha dari pemukiman masyarakat sekurang-kurangnya 100 meter. Jarak minimal lokasi usaha dari pemukiman masyarakat ini ditujukan untuk menjaga kenyamanan lingkungan masyarakat sehingga tidak terganggu aktivitas pengusahaan sarang burung walet yang tentunya menimbulkan suara yang cukup tidak nyaman.

Perihal

pembinaan, pengawasan dan pengendalian tercantum pada bab X pasal 18 ayat (1) yang berbunyi "Pembinaan, pengawasan dan pengendalian izin pengelolaan dan pengusahaan sarang burung walet dilaksanakan oleh Instansi yang ditetapkan oleh Walikota", dan ayat (2) yang berbunyi "Untuk kepentingan pengawasan dan pengendalian orang atau badan yang mengusahakan pengelolaaan dan pengusahaan sarang burung walet, wajib memberikan kesempatan kepada petugas untuk mengadakan pemeriksaan dan penelitian yang bersifat administratif maupun teknis operasional." Namun dalam proses implementasinya, pengawasan, pembinaan dan pengendalian tidak dilaksanakan oleh instansi terkait secara efektif. Hal tersebut dapat dilihat dari masih banyaknya usaha sarang burung walet di Pekanbaru yang menyalahi aturan dalam kebijakan dimaksud, serta tidak diberikan sanksi pidana maupun pencabutan izin usaha sarang burung waletnya. Pengawasan terhadap usaha sarang burung walet hanya dilaksanakan saat terdapat pengaduan dari masyarakat terhadap usaha sarang burung walet yang diindikasi melanggar Perda. Sanksi pidana bagi pengusaha yang tidak mematuhi aturan dalam Perda ini tercantum pada bab XII pasal 20 ayat (1), (2), dan (3). Kriteria pelanggaran yang diancam dengan sanksi pidana tersebut adalah pengusaha yang tidak memenuhi ketentuan pada pasal 6 (mengenai persyaratan memeproleh izin usaha sarangn burung walet); ketentuan pada bab $\mathrm{V}$ pasal 8 yang berbunyi "Point d Pasal 6 ayat (2) berlaku 5 (lima) tahun sejak Perda ini disahkan"; dan ketentuan pada bab VI pasal 9 ayat (1) yang berbunyi "Izin pengelolaan dan pengusahaan sarang burung walet berlaku maksimal selama 5 (lima) tahun dan dapat diperpanjang kembali atas persetujuan Walikota", dan pasal (2) yang berbunyi "Orang atau badan yang izinnya sudah berakhir wajib menghentikan kegiatannya.

Permohonan perpanjang izin pengelolaan dan pengusahaan sarang burung walet harus sudah diajukan selambat-lambatnya 1 (satu) bulan sebelum habis masa berlakunya kepada Walikota melalui Dinas Peternakan." Ketentuan pidana tercantum pada bab XII pasal 20 ayat (1) yang berbunyi "Barang siapa melanggar ketentuan sebagaimana dimaksud pasal 6,8, dan 9 dalam 
Peraturan Daerah ini diancam pidana kurungan paling lama 3 (tiga) bulan atau denda sebanyak - banyaknya Rp. 50.000.000,- (lima puluh juta rupiah)", pasal (2) yang berbunyi "Tindak Pidana yang dimaksud ayat (1) pasal ini adalah pelanggaran," dan pasal (3) yang berbunyi "Hasil denda sebagaimana dimaksud pada ayat (1) pasal ini disetorkan ke Kas Daerah." Pada proses implementasinya sejak tahun 2007 hingga 2020, instansi pemerintah terkait yang berwenang dalam izin usaha pengelolaan dan pengusahaan sarang burung walet belum pernah memproses pelanggaran yang terjadi dan memberikan sanksi pidana sesuai dengan ketentuan yang berlaku. Pengaduan masyarakat kepada instansi pemerintah yang berwenang terkait usaha sarang burung walet yang melanggar aturan diproses sebatas pengawasan langsung ke lokasi usaha tanpa memberikan sanksi. Hal ini turut mengambil andil dalam kecilnya angka presentase izin usaha sarang burng walet yang ada di Pekanbaru, karena tidak pernah ada tindakan tegas dari pelaksana kebijakan terhadap proses implementasi kebijakan dimaksud.Kewenangan izin usaha pengelolaan dan pengusahaan sarang burung walet di Kota Pekanbaru diberikan kepada Dinas Penanaman Modal dan Pelayanan Terpadu Satu Pintu (DPMPTSP) Kota Pekanbaru berdasarkan Peraturan Walikota Pekanbaru Nomor 260 Tahun 2017 tentang Kedudukan, Susunan Organisasi, Tugas dan Fungsi Serta Tata Kerja Dinas Penanaman Modal dan Pelayanan Terpadu Satu Pintu Kota Pekanbaru dan Peraturan Walikota Pekanbaru Nomor 15 Tahun 2019 Tentang Pendelegasian Wewenang Perizinan dan
Nonperizinan Kepada Kepala Dinas Penanaman Modal dan Pelayanan Terpadu Satu Pintu.

Implementasi kebijakan izin usaha pengelolaan dan pengusahaan sarang burung walet di Kota Pekanbaru dalam penelitian ini dikaji melalui empat dimensi yaitu: komunikasi, sumberdaya, disposisi dan struktur birokrasi.

\section{a. Komunikasi}

Komunikasi adalah suatu proses untuk menyampaikan informasi dari pemberi informasi atau komunikator kepada penerima informasi atau komunikan, sedangkan komunikasi yang dimaksud dalam penelitian ini adalah komunikasi kebijakan yang menjadi proses untuk menyampaikan informasi kebijakan dari pembuat kebijakan kepada pelaksana kebijakan dan kelompok sasaran (Sholiq dalam Ramadani, 2019:8). Hal tersebutlah yang menempatkan komunikasi merupakan aspek penting dalam implementasi kebijakan izin usaha pengelolaan dan pengusahaan sarang burung walet di Kota Pekanbaru, apabila pembuat kebijakan tidak melakukan komunikasi dengan baik dan jelas kepada pelaksana kebijakan maka implementasi kebijakan tidak sesuai dengan maksud yang dituangkan dalam kebijakan. Komunikasi pada implementasi kebijakan izin usaha pengelolaan dan pengusahaan sarang burung walet di Kota Pekanbaru dilihat dari proses penyampaian informasi kepada pelaksana kebijakan dan kelompok sasaran, serta dianalisis dari aspek media komunikasi yang digunakan dan ketepatan serta kejelasan informasi yang diterima.

Penyampaian tujuan dan sasaran kebijakan izin pengelolaan 
dan pengusahaan sarang burung walet kepada pelaksana kebijakan dilaksanakan melalui rapat koordinasi dengan instansi terkait. Komunikasi juga dilakukan secara vertikal dan horizontal. Dengan komunikasi yang cukup intens kepada pelaksana kebijakan maka pelaksana kebijakan izin usaha pengelolaan dan pengusahaan sarang burung walet di Kota Pekanbaru dapat menerima informasi dengan jelas serta konsisten sehingga implementor bisa memperoleh pengetahuan dan pemahaman mengenai hal yang menjadi standar pelaksanaan dan hal yang harus dilakukan oleh implementor.

Hal tersebut sesuai dengan yang disebutkan oleh Edward III dalam Agustino (2006:5) mengenai implementasi kebijakan yang mensyaratkan bagi pihak yang bertanggungjawab terhadap pelaksanaan kebijakan harus mengetahui hal-hal yang dilakukan agar pelaksanaan kebijakan berjalan secara efektif. Penyampaian perintah implementasi suatu kebijakan harus dilakukan secara jelas, akurat, dan konsisten kepada pihak-pihak yang menjadi pelaksana kebijakan. Pelaksana kebijakan yang ditunjuk beresiko mengalami kesalahpahaman saat pelaksanaan kebijakan yang diharapkan oleh pembuat kebijakan tampak tidak jelas terspesifikasikan. Jika terjadi kebingungan dan ketidakjelasan di pihak pelaksana kebijakan mengenai hal yang harus dilakukan untuk proses implementasi kebijakan maka membuka peluang keengganan pelaksana kebijakan untuk mengimplementasikan kebijakan sebagaimana dikehendaki oleh para pembuat kebijakan.

Penyampaian kebijakan kepada kelompok sasaran dilakukan melalui kegiatan sosialisasi. Kegiatan sosialisasi dilaksanakan dengan menghadirkan instansi terkait dan perwakilan pengusaha sarang burung walet di Pekanbaru. Selanjutnya kegiatan sosialisasi dilakukan langsung dengan mendatangi tempat usaha sarang burung walet. Namun kegiatan sosialisasi yang dilakukan belum memberikan hasil yang optimal karena sosialisasi yang dilakukan dengan door to door memiliki kendala besar, yaitu sulitnya menemui pemilik usaha sarang burung walet. Tersumbatnya penyampaian dan penyebaran informasi kepada kelompok sasaran kebijakan, berpengaruh langsung terhadap kejelasan dan konsistensi informasi baik bagi pengusaha sarang burung walet. McAvoy (2014:6) menyimpulkan bahwa sosialisasi sebuah kebijakan dapat difasilitasi dengan perencanaan yang cermat, konsultasi dan komunikasi yang luas, ditambah dengan pelatihan staf yang komprehensif, sehingga sosialisasi kebijakan yang dilakukan dapat mencapai tujuan komunikasi kebijakan terhadap kelompok sasaran dengan peningkatan pemahaman kelompok sasaran terhadap konten kebijakan.

Pelaksana kebijakan harus menyampaikan kepada kelompok sasaran mengenai tujuan dan sasaran kebijakan. Keberhasilan komunikasi ini didukung dengan pengetahuan pelaksana kebijakan yang harus tahu hal apa yang dilakukan dalam implementasi kebijakan. Implementasi kebijakan yang tidak efektif dapat berawal dari ketidaktahuan kelompok sasaran mengenai sasaran dan tujuan kebijakan sehingga menimbulkan resistensi dari kelompok sasaran (Koine, 2014:4). Seperti yang terjadi 
pada implementasi kebijakan izin usaha pengelolaan dan pengusahaan sarang burung walet di Kota Pekanbaru, di mana komunikasi dari pelaksana kebijakan kepada kelompok sasaran berjalan secara tidak efektif yang mengakibatkan dampak pada minimnya usaha sarang burung walet yang memiliki izin. Edward III (dalam Agustino, 2006:5) menjelaskan beberapa hambatan dalam transmisi komunikasi, yaitu : (1) Adanya pertentangan antara pelaksana kebijakan dengan perintah yang dikeluarkan oleh pembuat kebijakan, yang berakibat distorsi dan hambatan yang langsung dalam komunikasi kebijakan.(2) Informasi yang disampaikan melalui berlapislapis hirarki birokrasi, yang menyebabkan distorsi komunikasi karena panjangnya rantai informasi yang dapat mengakibatkan bias informasi. (3) Masalah persepsi dan ketidakmampuan pelaksana kebijakan dalam memahami persyaratan-persyaratan suatu kebijakan. Kelompok sasaran akan menerima sebuah kebijakan bergantung pada kualitas komunikasi yang dilakukan oleh pelaksana kebijakan. Kualitas komunikasi pada akhirnya akan mempengaruhi efektivitas implementasi kebijakan publik. Dengan kata lain, penyampaian konten kebijakan melalui komunikasi yang berkualitas akan mendukung proses implementasi kebijakan. Penggunaan media komunikasi juga menentukan penyebarluasan konten kebijakan kepada kelompok sasaran. Hal ini sejalan dengan pendapat Agustino (dalam Nurwanda, 2017:8) yang menyatakan bahwa keberhasilan kinerja implementasi kebijakan diukur dari ukuran dan tujuan kebijakan yang realistis dengan sosial kultural yang ada di level pelaksana kebijakan dan kelompok sasaran.

\section{b. Sumber Daya}

Pelaksanaan

kebijakan

memerlukan dukungan sumberdaya manusia (human resources) maupun sumberdaya non-manusia (nonhuman resources). Implementasi kebijakan tidak akan berjalan efektif jika sumber daya yang dibutuhkan tidak memadai, bahkan dalam keadaan jika komunikasi kebijakan telah dilakukan secara jelas dan konsisten tetap membutuhkan dukungan sumber daya. Sebaikbaiknya kebijakan, jika tidak ada sumber daya manusianya maka pelaksanannya hanya tinggal kebijakan semata. Namun meskipun kebijakan dirancang baik dan aparat pelaksana juga telah memadai, bila tanpa didukung anggaran, kewenangan dan fasilitas maka kebijakan tersebut akan menemui berbagai hambatan atau bahkan gagal dilaksanakan.Sumber daya manusia aparatur menjadi hal yang penting dalam implementasi kebijakan izin usaha pengelolaan dan pengusahaan sarang burung walet di Pekanbaru. Sumber daya manusia aparatur yang tidak mencukupi dan tidak kompeten sering kali menjadi penyebab kegagalan dalam proses implementasi kebijakan. Seperti dalam implementasi kebijakan izin usaha pengelolaan dan pengusahaan sarang burung walet di Pekanbaru yang masih kekurangan staf di DPMPTSP Kota Pekanbaru. Walaupun dengan jumlah staf yang lebih dari seratus orang, namun beban kerja di instansi tersebut cukup tinggi dan melayani perizinan dan non perizinan sekitar 88 jenis perizinan yang ada di DPMPTSP Kota Pekanbaru dan ada 66 jenis perizinan yang dapat didaftarkan secara online, belum lagi 
ditambah dengan beban tugas bidang penanaman modal dan investasi. Peningkatan kuantitas staf juga harus dibarengi dengan kualitas kompetensinya agar tidak menjadi penghambat pencapaian tujuan implementasi kebijakan. Sidik (2014:7) menyatakan bahwa dalam proses implementasi kebijakan, kapasitas sebuah organisasi untuk menjalankan misinya dalam pencapaian tujuan organisasi dipengaruhi oleh jumlah dan kualitas SDM yang dimiliki organisasi tersebut. Kepastian ketepatan jumlah SDM yang harus dimiliki oleh sebuah organisasi dalam menjalankan fungsinya tidak tercermin dalam sebuah rumusan baku. Penentuan beban kerja sebuah organisasi yang akan jumlah SDM yang harus dimiliki oleh organisasi agar dapat menjalankan tugasnya secara optimal. Jumlah SDM juga ditentukan dengan kompleksitas sebuah kebijakan yang akan diimplementasikan. Hal tersebut sesuai dengan kondisi jumlah SDM di DPMPTSP Kota Pekanbaru dimana memerlukan peningkatan kuantitas karena beban kerja yang cukup tinggi disebabkan pelayanan perizinan dan non perizinan yang terpusat di instansi ini. Hal ini sejalan dengan pendapat Agustino (dalam Nurwanda, 2017:8) bahwa kemampuan dalam pemanfaatan sumber daya yang tersedia mempengaruhi keberhasilan proses pelaksanaan sebuah kebijakan. Sumber daya manusia menjadi salah satu yang penting dalam penentu proses keberhasilan pelaksanaan kebijakan. Kualitas dan kompetensi sumber daya manusia mempengaruhi kinerja implementasi kebijakan karena pada tahapan tertentu proses pelaksanaan kebijakan publik menuntut ketersediaan sumber daya manusia yang mampu menjalankan tugas dan fungsinya sesuai dengan pekerjaan yang diisyaratkan oleh kebijakan yang tclah ditetapkan secara politik. Elsye (2014:9) menyatakan bahwa pengembangan sumber daya manusia yang dilakukan secara berkelanjutan akan menghasilkan kualitas dalam artian yang sebenarnya.

$\begin{array}{cccr}\text { Hasil } & \text { pekerjaan } & \text { yang } \\ \text { dilaksanakan } & \text { oleh } & \text { SDM yang } \\ \text { bersangkutan } & \text { akan } & \text { menghasilkan }\end{array}$ keluaran yang sesuai dengan target capaian. Persoalan anggaran dan fasilitas juga menjadi perhatian tersendiri dalam implementasi kebijakan izin usaha pengelolaan dan pengusahaan sarang burung walet di Pekanbaru. Anggaran seta fasilitas dinilai memerlukan peningkatan agar implementasi kebijakan dimaksud dapat lebih efektif. Elsye (2014:10) menyatakan bahwa dalam rangka memberikan motivasi dan dorongan untuk para pegawai, sumber daya anggaran seharusnya bersifat challenging but attainable atau demanding but achieveable. Sumber daya anggaran yang disediakan memiliki target realisasi yang seharusnya tidak terlalu besar atau tinggi sehingga dapat tercapai realisasi yang direncanakan. Namun juga target realisasi anggaran seharusnya tidak terlalu rendah sehingga terlalu mudah untuk dicapai.

\section{c. Disposisi}

Proses

implementasi kebijakan membutuhkan disposisi atau sikap pelaksana kebijakan yang merupakan kecenderungan, keinginan maupun kesepakatan pelaksana kebijakan untuk pelaksanaan kebijakan agar tercapai tujuan akhir. Sikap pelaksana 
kebijakan berkaitan dengan kesadaran pelaksana kebijakan terhadap keseluruhan bagian tugas dan fungsi yang menjadi tanggung jawabnya serta memberikan dampak yang positif atau negatif terhadap kinerja organisasi dan penyelesaian tanggungjawab itu sendiri sesuai standar yang disepakati. Disposisi pada proses pelaksanaan kebijakan izin pengusahaan dan pengelolaan sarang burung walet di Kota Pekanbaru dianalisis berdasarkan kemampuan pelaksana kebijakan dan komitmen pelaksana kebijakan.Berhasil atau tidaknya sebuah pelaksanaan kebijakan erat kaitannya dengan sikap para pelaksana kebijakan. Sikap ini dapat berasal dari motivasi seorang implementor dalam menjalankan kewajibannya, seta pemahaman setiap implementor mengenai kebijakan yang mereka lakukan.

Sikap pelaksana kebijakan izin usaha pengelolaan dan pengusahaan sarang burung walet di Pekanbaru menjadi faktor penting dalam proses implementasi. Apabila pelaksana kebijakan memiliki pandangan yang positif pada kebijakan, maka pelaksana kebijakan akan menjalankan implementasi kebijakan dimaksud, namun jika terdapat pandangan atau perspektif berbeda, maka pelaksanaan kebijakan beresiko mengalami hambatan dan gagal (Elsye, 2014:10). Pelaksana kebijakan izin usaha pengelolaan dan pengusahaan sarang burung walet di Pekanbaru sangat mendukung pelaksanaan kebijakan ini dikarenakan tujuan kebijakan untuk mengatur ketertiban lokasi usaha sarang burung walet yang sudah terlalu banyak berdiri di dekat perumahan warga, dan pada akhirnya untuk peningkatan kualitas dan kenyamanan lingkungan. Proses implementasi kebijakan berkaitan terhadap banyak kegiatan yang menjadi penjabaran pelaksanaan tujuan program dan hasil kebijakan publik yang diharapkan oleh pembuat kebijakan.

Oleh karena itu, implementasi kebijakan merupakan proses membangun interaksi antara penentuan tujuan kebijakan serta tindakan dalam rangka pencapaian tujuan kebijakan. Hal tersebut secara prinsip merupakan kemampuan dari pelaksana kebijakan untuk membangun hubungan dalam mata rantai sebab akibat agar kebijakan bisa berdampak (Parsons dalam Kurniawan, 2011:7). Seperti kemampuan pelaksana kebijakan izin usaha pengelolaan dan pengusahaan sarang burung walet di Pekanbaru yang dinilai sudah baik sehingga pelaksanaan pekerjaan pelayanan tidak terhambat aspek kemampuan.

Kemampuan ini juga merujuk pada kemampuan untuk membangun hubungan dengan sesama pelaksanan kebijakan sehingga hubungan kerjasama dan koordinasi dapat tercipta dengan optimal.Suyatna (2019:10) menyatakan bahwa keberhasilan implementor mengimplementasikan suatu kebijakan, akan sangat tergantung pada kemampuannya dalam merealisasikan aktivitas organization, interpretation, dan application. Organization menjadi aktivitas yang mencakup penataan kembali sumber daya, unit, dan metode pada organisasi yang mengarah pada proses menerapkan kebijakan agar diperoleh hasil yang sesuai dengan tujuan dan sasaran kebijakan. Dalam implementasi kebijakan, organisasi termasuk di dalamnya adalah cakupan pola kewenangan formal dan 
informal, pembagian kerja di antara banyak komponen, saluran komunikasi di antara anggota organisasi. Interpretation merupakan operasionalisasi sebuah kebijakan agar lebih mudah dipahami sehingga apa yang menjadi substansi sebuah kebijakan terlaksana dan diterapkan, serta mendapatkan penerimaan oleh pelaksana kebijakan dan sasaran kebijakan.

Oleh karena itu, interpretasi adalah proses menafsirkan sejumlah program turunan maupun rencana lanjutan beserta pemahaman, arahan dan petunjuk yang tepat, jelas, bisa diterima dan diterapkan. Efektivitas implementasi kebijakan juga dipengaruhi oleh interpretasi khususnya berpengaruh kepada pihak-pihak yang terlibat selama proses implementasi. Application adalah penyediaan pelayanan kebijakan secara rutin sesuai dengan tujuan dan sasaran kebijakan yang telah ditetapkan. Dengan application ini, proses implementasi kebijakan diharapkan muncul adanya respon masyarakat, apakah menerima atau menolak hasil kebijakan itu.

Aspek disposisi pelaksana kebijakan lainnya, yaitu komitmen yang menjadi faktor yang turut berpengaruh dalam proses implementasi kebijakan. Komitmen yang kuat dari pelaksana kebijakan dan kelompok sasaran kebijakan memiliki dampak positif pada pencapaian keberhasilan proses implementasi kebijakan. Melalui pembentukan komitmen dari seluruh pelaksana kebijakan dan kelompok sasaran kebijakan, sejumlah masalah dan hambatan yang ditemui dalam proses implementasi kebijakan dapat diatasi dan dicarikan solusinya karena setiap pelaksana kebijakan akan berpikir dan bertindak untuk keberhasilan implementasi kebijakan mencapai tujuan kebijakan (Putera, 2011:9).

Komitmen

pelaksana kebijakan untuk mensukseskan implementasi kebijakan izin usaha pengelolaan dan pengusahaan sarang burung walet di Kota Pekanbaru dinilai belum optimal apalagi dalam proses pelaksanaannya terdapat banyak faktor yang menjadi sebab tidak efektifnya sebuah kebijakan. Komitmen yang lemah dari para pelaksana kebijakan tampak dalam proses pengawasan implementasi kebijakan. Hal ini juga karena minimnya anggaran untuk proses pengawasan yang melibatkan beberapa instansi terkait. Dalam kenyataannya, kurangnya komitmen pelaksana kebijakan tampak pada ketiadaan penerapan sanksi yang tegas bagi usaha sarang burung walet yang melanggar aturan.

Edward III (dalam Sidik, 2014:9) menjelaskan mengenai faktor yang mempengaruhi disposisi dalam implementasi kebijakan, yaitu(1) Pengangkatan birokrasi. Disposisi pelaksana kebijakan beresiko menimbulkan masalah dan hambatan tetrhadap proses implementasi kebijakan saat pelaksana kebijakan tidak melaksanakan kebijakan sebagaimana yang diharapkan pembuat kebijakan.

Oleh karena itu, pemilihan dan penetapan aparatur pelaksana kebijakan harus melalui mekanisme yang dapat menyeleksi orang-orang terbaik dan berdedikasi tinggi terhadap pelaksanaan kebijakan terutama untuk memenuhi kepentingan masyarakat yang lebih luas. (2) Insentif .Manipulasi insentif menjadi salah satu teknik untuk mengatasi hambatan dan masalah 
sikap pelaksana kebijakan. Dengan dasar pemikiran bahwa setiap anggota organisasi melakukan pekerjaan berdasarkan kepentingan pribadi sehingga pemanipulasian insentif yang dilakukan pembuat kebijakan akan memberikan pengaruh pada sikap pelaksana kebijakan. Insentif yang diberikan melalui penambahan keuntungan dan biaya tertentu dapat menjadi faktor yang mendorong pelaksana kebijakan melaksanakan kebijakan secara optimal karena penambahan insentif dalam upaya memenuhi kepentingan pribadi atau organisasi. Ketidakberhasilan implementasi kebijakan disebabkan oleh beberapa faktor antara lain kepentingan politik yang dominan dalam tahap implementasi, ketidaktegasan pemerintah dalam menegakan aturan, ketidakpatuhan dan minimya daya tanggap pelaksana, ketidaktransparanan pengalihan peran pemerintah ke swasta, ketidakefektifan kontrol birokratik dan politik (Budiawan, 2019:10). Pernyataan tersebut juga terjadi pada implementasi kebijakan izin usaha pengusahaan dan pengelolaan sarang burung walet di Pekanbaru, di mana ketidakefektifan proses implementasi disebabkan oleh sanksi tegas yang tidak pernah diberikan instansi pemerintah terkait terhadap pengusaha sarang burung walet yang dinilai melanggar aturan di Perda.

\section{d. Struktur Birokrasi}

Struktur birokrasi ditujukan untuk mempermudah koordinasi dan pembagian tugas dalam implementasi kebijakan pemerintah. Secara teoritis, proses pelaksanaan suatu kebijakan pada organisasi yang menggunakan simple structure berpeluang lebih besar untuk berhasil daripada pelaksanaan kebijakan di suatu organisasi dengan complex structure (Sidik, 2014:11). Implementasi kebijakan dengan simple structure hanya melibatkan satu instansi atau organisasi tunggal. Implementasi kebijakan yang menggunakan complex structure memanfaatkan pelibatan banyak pihak atau organisasi yang beragam namun masih terkait dalam pelaksanaan kebijakan dimaksud.

Banyaknya pihak yang terlibat dalam proses implementasi kebijakan berimplikasi pada komunikasi, komando, koordinasi dan pengawasan yang tentunya akan lebih sulit untuk dilaksanakan. Kompleksnya keterlibatan banyak pihak juga tampak pada implementasi kebijakan izin usaha pengelolaan dan pengusahaan sarang burung walet di Pekanbaru yang tidak hanya melibatkan DPMPTSP Kota Pekanbaru, namun juga beberapa dinas terkait lainnya. Struktur organisasi dari instansiinstansi yang terlibat dalam proses implementasi kebijakan dimaksud akan memberikan pengaruh pada efektivitas implementasi kebijakan. Prosedur dan tingkatan birokrasi yang rumit dan kompleks akan menyebabkan aktivitas organisasi tidak efektif (Sidik, 2014:12). Marquardt (2017:8) dalam penelitiannya menunjukkan bahwa koordinasi dan hubungan kekuatan berdampak pada implementasi kebijakan. Koordinasi lintas sektor menjadi kunci dalam pelaksanaan kebijakan. Kekurangan dalam paksaan hukum dan koordinasi dengan otoritas lokal yang kuat menjadi alasan utama terhambatnya proses implementasi. Koordinasi lintas level yang berbeda dan distribusi kekuatan dalam tatanan 
governance yang kompleks perlu dipertimbangkan lebih serius dalam pelaksanaan kebijakan. Penyertaan otoritas lokal dan pembangunan kapasitas menjadi penting untuk efektifitas implementasi kebijakan.

Struktur birokrasi dalam implementasi kebijakan izin usaha pengelolaan dan pengusahaan sarang burung walet di Pekanbaru dianalisis berdasarkan ketersediaan SOP, fragmentasi dan koordinasi antar pelaksana kebijakan. SOP dalam implementasi kebijakan izin usaha pengelolaan dan pengusahaan sarang burung walet di Pekanbaru sudah tersedia, dilengkapi dengan dasar hukum kebijakan, kualifikasi pelaksana kebijakan, alur pelayanan, biaya pelayanan dan waktu pelayanan. SOP menjadi perkembangan dari tuntutan masyarakat akan kepastian waktu, sumber daya serta kebutuhan penyeragaman dalam organisasi kerja yang kompleks dan luas terhadap pelaksanaan proses pelayanan masyarakat. SOP seharusnya dapat diakses dengan mudah oleh pengguna pelayanan, seperti yang terjadi pada proses pelayanan izin usaha pengelolaan dan pengusahaan sarang burung walet di DPMPTSP Kota Pekanbaru di mana SOP dapat diakses dengan mudah melalui website DPMPTSP Kota Pekanbaru.

Fragmentasi menjadi aspek lainnya yang dianalisis dari komponen struktur birokrasi dalam proses implementasi kebijakan. Edward III (dalam Sidik, 2014:12) menyebutkan fragmentasi sebagai penyebaran tanggung jawab suatu kebijakan kepada beberapa badan yang berbeda sehingga memerlukan koordinasi. Fragmentasi dalam implementasi kebijakan izin usaha pengelolaan dan pengusahaan sarang burung walet di Kota Pekanbaru dapat dilihat melalui penyebaran tugas dan fungsi yang berbeda dalam mendukung keberhasilan pelaksanaan kebijakan dimaksud dalam tugas pokok dan fungsi DPMPTSP Kota Pekanbaru dan seluruh instansi yang menjadi anggota Tim Teknis. Keberhasilan implementasi kebijakan dipengaruhi oleh koordinasi yang dibutuhkan di antara unit-unit yang bertanggungjawab. Semakin besar koordinasi yang dibutuhkan, beresiko pada berkurangnya kesempatan berhasil sebuah kebijakan.

Fragmentasi pada struktur birokrasi dapat menimbulkan beberapa hambatan pada proses pelaksanaan kebijakan (Sidik, 2014:15), antara lain: (1) Terpecahnya beberapa fungsi pada sejumlah unit yang terkait dalam proses implementasi kebijakan dapat menyebabkan ketiadaan otoritas yang kuat pada pelaksanaan kebijakan. Masing-masing unit pelaksana kebijakan memiliki keterbatasan yurisdiksi sehingga memungkinkan terabaikannya sejumlah tugas penting karena agenda birokrasi yang menumpuk. (2) Kemungkinan unit pelaksana kebijakan yang memiliki pandangan sempit sehingga dapat menghambat perubahan. Saat suatu unit pelaksana kebijakan memiliki fleksibilitas rendah dalam melaksanakan misinya, maka unit tersebut mempertahankan esensinya serta beresiko tidak mendukung kebijakan baru yang menuntut perubahan. Mueller (2020:8) dalam penelitiannya menyimpulkan bahwa membina dan menciptakan kolaborasi yang berkelanjutan di antara pembuat kebijakan dan seluruh stakeholders 
terkait akan membantu terhadap penerimaan pelaksanaan kebijakan.

Kerjasama dan koordinasi yang terjadi dalam implementasi kebijakan izin usaha pengelolaan dan pengusahaan sarang burung walet di Kota Pekanbaru dilakukan dengan baik dan optimal saat proses peninjauan langsung ke lokasi usaha untuk penilaian kelayakan pemberian izin usaha. Koordinasi terjadi antara DPMPTSP dan seluruh instansi yang termasuk dalam Tim Teknis. Namun koordinasi yang dilakukan dalam proses pengawasan implementasi kebijakan dimaksud masih belum optimal, ditunjukkan dengan masih banyaknya lokasi usaha sarang burung walet yang berada dekat dengan pemukiman masyarakat. Pengawasan dilakukan hanya saat terdapat pengaduan dari masyarakat mengenai lokasi usaha sarang burung walet yang diduga melanggar aturan. Tentunya saat pengawasan hanya dilakukan setelah ada pengaduan masyarakat maka tidak tampak komitmen yang kuat dari pemerintah daerah untuk melakukan monitoring terhadap keberadaan lokasi usaha sarang burung walet yang mengganggu kualitas lingkungan dan kenyamanan masyarakat.

Giest (2019:9) menyatakan bahwa implementasi kebijakan pada dasarnya adalah masalah dalam mengkoordinasikan berbagai lembaga untuk bekerja sama menuju produk kebijakan yang sama. Kerangka koordinasi kebijakan dengan demikian menyoroti saling ketergantungan di antara badanbadan pelaksana dan efek dari tindakan atau kelambanan satu sama lain, yang mengakibatkan aplikasi menjadi lambat atau terhenti. Koordinasi kebijakan didefinisikan sebagai koordinasi di berbagai jenis kebijakan (terkait) dan berbagai jenis pelaku. Tujuan koordinasi adalah untuk meminimalkan duplikasi dan tumpang tindih, menghindari ketidakkonsistenan, meminimalkan konflik dan bertujuan untuk perspektif yang komprehensif dari suatu masalah.

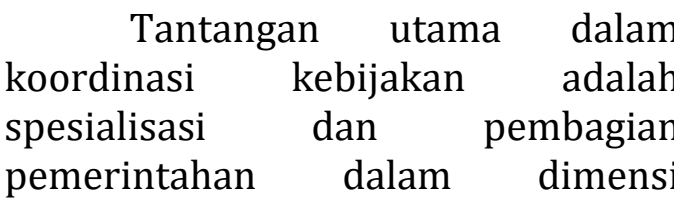
horizontal dan vertikal. Koordinasi horizontal adalah interaksi organisasi pada tingkatan hierarki yang sama, sedangkan koordinasi vertikal mengacu pada dinamika antar tingkat pemerintahan. Seharusnya hal tersebut dapat menjadi pertimbangan bagi pelaksana kebijakan dalam implementasi kebijakan izin usaha pengelolaan dan pengusahaan sarang burung walet terkait proses koordinasi di antara banyak instansi pemerintah yang terlibat dalam proses kebijakan dimaksud. Pelibatan tim teknis dari berbagai instansi pemerintah terkait bidang pengusahaan sarang burung walet menjadi tantangan tersendiri agar proses koordinasi dari peninjauan lapangan, penilaian, pembahasan hingga pengawasan dapat dilaksanakan dengan maksimal.

\section{Faktor Pendukung dan Penghambat Implementasi Kebijakan Izin Pengelolaan dan Pengusahaan Sarang Burung Walet di Kota Pekanbaru \\ a. Faktor Internal}

Faktor internal disini meliputi substansi kebijakan dan sumber daya. Faktor pertama adalah Substansi Kebijakan,Implementasi kebijakan izin usaha pengelolaan dan pengusahaan sarang burung walet di Pekanbaru dapat berjalan efektif jika 
didukung oleh subtansi kebijakan yang memiliki tujuan, asumsi dan informasi kebijakan yang jelas, realistis dan terbaru. Grindle (dalam Rahmawati, 2019:9) menyatakan bahwa tugas implementasi suatu kebijakan, yaitu membangun sebuah kaitan (linkage) yang mempermudah tujuan kebijakan dapat direalisasikan secara optimal karena merupakan kegiatan pemerintah. Implementasi kebijakan memiliki tugas untuk membentuk "a policy delivery system", kondisi di mana sarana dan sumber daya direncanakan dan dilaksanakan untuk proses pencapaian tujuan kebijakan yang telah ditetapkan.

Implementasi kebijakan izin usaha pengelolaan dan pengusahaan sarang burung walet di Kota Pekanbaru yang memiliki tujuan kebijakan dan asumsi kebijakan yang jelas dan realistis sehingga dalam proses implementasinya kedua hal tersebut menjadi salah satu faktor pendukung proses implementasi kebijakan. Perihal aspek informasi yang benar dan terbaru dalam perumusan kebijakan, hal ini menjadi faktor penghambat karena informasi mengenai jarak minimal lokasi usaha sarang burung walet yang tercantum dalam kebijakan dimaksud tidak disesuaikan dengan penemuan penelitian terbaru sehingga dibutuhkan revisi kebijakan agar tujuan kebijakan untuk menjaga kualitas lingkungan di lokasi usaha sarang burung walet dapat diwujudkan.

Oleh karena itu, informasi menjadi faktor penghambat implementasi kebijakan karena konten kebijakan yang belum diperbaharui sehingga dibutuhkan kajian lebih mendalam mengenai lokasi yang layak untuk usaha sarang burung walet.Faktor kedua ,
Implementasi kebijakan izin usaha pengelolaan dan pengusahaan sarang burung walet di Kota Pekanbaru harus didukung oleh ketersediaan sumberdaya. Implementasi sebuah kebijakan menuntut pelaksanaan yang dilakukan secara cermat, jelas, serta konsisten sehingga sumber daya menjadi salah satu aspek penting untuk mencapai efektivitas implementasi kebijakan (Afandi \& Warjio dalam Ramdhani, 2017:5). Sejalan dengan Ramadani (2019:7) yang menyatakan bahwa pelaksana kebijakan dapat menerima perintah untuk melaksanakan sebuah kebijakan, namun jika pelaksana kebijakan mengalami kekurangan sumber daya pendukung maka proses implementasi kebijakan pada akhirnya akan terhambat dan terancam gagal. Hal ini dapat dilihat pada proses pelaksanaan kebijakan izin usaha pengelolaan dan pengusahaan sarang burung walet di Kota Pekanbaru yang kekurangan jumlah pelaksana kebijakan, fasilitas dan anggaran. Jumlah SDM di DPMPTSP Kota Pekanbaru sebanyak 203 orang. Namun jumlah yang banyak ini masih juga dinilai kurang untuk melaksanakan tugas seharihari karena terdapat 88 jenis perizinan yang ada di DPMPTSP Kota Pekanbaru dan ada 66 jenis perizinan yang dapat didaftarkan secara online yang menjadi beban kerja instansi tersebut. Seperti yang diketahui bahwa DPMPTSP Kota Pekanbaru terdiri dari 1 sekretariat dan 7 bidang tugas, yaitu Bidang Perencanaan, Pengembangan Iklim dan Promosi Penanaman Modal, Bidang Pengendalian Pelaksanaan, Pengolahan Data dan Informasi Penanaman Modal, Bidang Pendataan, Arsip dan Pengembangan Sistem, Bidang Penyelenggaraan 
Pelayanan Perizinan dan Non Perizinan A, Bidang Penyelenggaraan Pelayanan Perizinan dan Non Perizinan B, Bidang Penyelenggaraan Pelayanan Perizinan dan Non Perizinan $\mathrm{C}$, dan Bidang Pengaduan, Kebijakan dan Pelaporan Layanan. Dengan banyaknya bidang tugas DPMPTSP Kota Pekanbaru maka akan sebanding dengan beban tugasnya sehari-hari, sehingga jumlah SDM yang ada sekarang masih nilai kurang mencukupi. Persoalan fasilitas juga menjadi perhatian sendiri karena menjadi salah satu penghambat, yaitu mengenai ketersediaan kendaraan operasional yang dinilai tidak dapat mencukupi kebutuhan mobilitas pelaksanaan tugas sehari-hari. Kendaraan operasional hanya tersedia 6 mobil dan 1 motor operasional sehingga dinilai sangat minim untuk kebutuhan tugas seharihari yang membutuhkan koordinasi dengan instansi terkait. Ketersediaan anggaran juga menjadi salah satu penghambat implementasi kebijakan usaha pengelolaan dan pengusahaan sarang burung walet di pekanbaru karena minimnya alokasi anggaran di DPMPTSP Kota Pekanbaru.

\section{a. Faktor Eksternal}

Faktor ekternal adalah Kondisi Lingkungan Kebijakan dan dukungan masyarakat. Faktor pertama , Lingkungan kebijakan menjadi hal yang mempengaruhi implementasi kebijakan izin usaha pengelolaan dan pengusahaan sarang burung walet di Pekanbaru. Kondisi politik serta kondisi sosial sangat mendukung implementasi kebijakan dimaksud, namun kondisi ekonomi yang berkaitan dengan dukungan anggaran masih sangat terbatas sehingga menjadi salah satu hambatan implementasi kebijakan izin usaha pengelolaan dan pengusahaan sarang burung walet di Pekanbaru. Berdasarkan pendapat Warwick (dalam Lambelanova, 2017:7) menyatakan bahwa kecenderungan kepentingan elit politik yang menghambat dalam proses implementasi kebijakan justru dapat berbalik menjadi faktor yang mendorong proses pelaksanaan kebijakan jika terjadi komitmen politik antara stakeholders di level atas, masuk di dalamnya interest group dan pressure group, dalam mencapai keberhasilan pelaksanaan kebijakan dengan mengakomodir kebutuhan masyarakat untuk mempercepat terwujudnya tujuan kebijakan.

Hal ini sesuai dengan kondisi politik di Pekanbaru yang mendukung implementasi kebijakan izin usaha pengelolaan dan pengusahaan sarang burung walet di Pekanbaru, di mana tekanan dari pihak legislatif justru menjadi dukungan kuat dari politik untuk kesuksesan implementasi kebijakan dimaksud. Walaupun terdapat kepentingan dari elit politik dibalik tekanan dan dukungan tersebut, namun tidak dapat disangkal bahwa kondisi politik seperti ini justru menjadi dorongan bagi pihak eksekutif untuk meningkatkan kinerja agar terjadi peningkatan jumlah izin usaha sarang burung walet yang berdampak positif pada retribusi yang berpotensi besar menjadi pendapatan daerah. Faktor kedua, Dukungan Masyarakat, Masyarakat Kota Pekanbaru sangat mendukung dalam implementasi kebijakan izin usaha pengelolaan dan pengusahaan sarang burung walet di Pekanbaru. Dukungan diberikan dalam bentuk peran serta masyarakat yang melakukan pengaduan ke 
instansi terkait jika didapati lokasi usaha sarang burung walet yang diduga menyalahi aturan. Dukungan masyarakat dalam implementasi sebuah kebijakan akan menjadi salah satu aspek pendorong pelaksanaan kebijakan yang ditujukan untuk menyelesaikan masalah publik.

Berdasarkan hasil penelitian Lambelanova (2017:15) Brian W. Hogwood dan Lewis A. Gunn (dalam Nugroho, 2018:268), dan Grindle (dalam Lambelanova, 2017:8) menyatakan bahwa dukungan stakeholders yang memiliki akses luas terhadap sumber daya diperlukan dalam proses implementasi kebijakan. Sehingga partisipasi masyarakat perlu distimulus untuk pemberian ruang yang lebih luas dan terbuka bagi masyarakat ekonomi dan sosial melalui kerjasama yang baik dan lebih intens dengan stakeholders dalam proses pelaksanaan kebijakan yaitu pihak swasta, masyarakat dan unsur perguruan tinggi (public private partnership).

\section{Kesimpulan}

Dari hasil penelitian disimpulkan bahwa implementasi kebijakan izin usaha pengelolaan dan pengusahaan sarang burung walet di Kota Pekanbaru belum dilaksanakan secara efektif. Dilihat dari dimensi komunikasi, selama ini Komunikasi dengan pelaksana kebijakan menggunakan media rapat koordinasi dan perintah langsung dari atasan. Pelaksana kebijakan memiliki pengetahuan yang cukup baik mengenai sasaran dan tujuan kebijakan, serta prosedur dan persyaratan yang harus dipenuhi dalam proses permohonan izin usaha sarang burung walet. Komunikasi dengan kelompok sasaran dilaksanakan melalui sosialisasi, namun tidak efektif.

Terhambatnya komunikasi berdampak pada keterbatasan informasi dalam kelompok sasaran mengenai sasaran dan tujuan kebijakan. Dilihat dari dimensi sumber daya ,sumber daya aparatur, anggaran, kewenangan dan fasilitas. Kemampuan SDM aparatur dalam menjalankan tugasnya sudah cukup baik. Namun, kuantitas SDM aparatur di DPMPTSP Kota Pekanbaru dan tim teknis masih terbatas. Anggaran yang tersedia untuk kegiatan penyelenggaraan izin usaha sarang burung walet masih belum optimal untuk implementasi kebijakan yang lebih efektif. Kewenangan DPMPTSP Kota Pekanbaru memiliki dasar hukum, yaitu Peraturan Walikota Pekanbaru Nomor 15 Tahun 2019 Tentang Pendelegasian Wewenang Perizinan dan Nonperizinan Kepada Kepala Dinas Penanaman Modal dan Pelayanan Terpadu Satu Pintu. Ketersediaan fasilitas perlengkapan kerja dinilai kurang memadai untuk menunjang pelaksanaan tugas seluruh pejabat dan pegawai di jajaran DPMPTSP Kota Pekanbaru. Dilihat dari dimensi disposisi, dari kemampuan dan komitmen pelaksana kebijakan. Kemampuan para pelaksana kebijakan secara administratif tergolong sudah baik. Komitmen pelaksana kebijakan cenderung masih kurang, dibuktikan dengan tidak ada pengawasan yang konsisten untuk menertibkan usaha sarang burung walet yang menyalahi aturan, serta tidak adanya tindakan tegas melalui pemberian sanksi bagi pengusaha yang tidak memiliki dan menyalahi izin.Dilihat dari dimensi struktur birokrasi, Struktur birokrasi dilihat dari ketersediaan SOP, 
fragmentasi dan koordinasi. SOP sudah tersedia dan dapat diakses melalui website DPMPTSP Kota Pekanbaru. Fragmentasi tercermin berdasarkan tugas pokok dan fungsi DPMPTSP beserta instansi tim teknis yang terlibat dalam kebijakan. Koordinasi dalam proses pelayanan pengurusan izin usaha berjalan dengan baik. Namun koordinasi dalam proses pengawasan tidak dilakukan secara konsisten.

Faktor Pendukung dan Penghambat Implementasi Kebijakan Izin Usaha Pengelolaan dan Pengusahaan Sarang Burung Walet di Kota Pekanbaru. Ada dua faktor yang dikaji dalam penelitian ini yaitu : Faktor Internal (Substansi Kebijakan dan Sumber Daya) dan Faktor eksternal (Kondisi Lingkungan Kebijakan dan Dukungan Masyarakat). Dalam substansi kebijakan, tujuan dan asumsi kebijakan menjadi faktor pendukung karena kebijakan memiliki tujuan yang jelas dan dapat dicapai, serta asumsi yang bersifat realistis. Namun, informasi yang menjadi dasar perumusan kebijakan menjadi faktor penghambat karena persyaratan mengenai jarak minimal usaha saranng burung walet dari permukiman masyarakat tidak disesuaikan dengan penelitian terkini.Sumber daya manusia, finansial dan fasilitas menjadi faktor penghambat. Kuantitas SDM aparatur masih terbatas. Anggaran yang tersedia belum optimal untuk implementasi kebijakan yang lebih efektif. Ketersediaan fasilitas perlengkapan kerja dinilai kurang memadai. Sumber daya kewenangan menjadi faktor pendukung karena kewenangan DPMPTSP Kota Pekanbaru memiliki dasar hukum yang jelas, yaitu Peraturan Walikota Pekanbaru Nomor 15 Tahun 2019 Tentang Pendelegasian Wewenang Perizinan dan Nonperizinan Kepada Kepala Dinas Penanaman Modal dan Pelayanan Terpadu Satu Pintu.

Kondisi ekonomi dalam lingkungan kebijakan menjadi faktor penghambat karena kurangnya dukungan finansial dari pemerintah untuk implementasi kebijakan dimaksud. Kondisi politik dan sosial menjadi faktor pendukung karena dukungan dari kalangan legislatif sangat besar agar pemerintah memaksimalkan upaya implementasi kebijakan ini. Kondisi sosial didukung oleh partisipasi masyarakat yang besar dalam mengawasi usaha sarang burung walet yang diduga menyalahi aturan. Dukungan sebagian besar masyarakat menjadi faktor pendukung. Masyarakat umum meyakini jika kebijakan diterapkan dengan efektif dan sanksi yang tegas maka akan menertibkan usaha sarang burung walet yang banyak menyalahi aturan dan menyebabkan dampak lingkungan di Kota Pekanbaru.

Komunikasi dengan kelompok sasaran kebijakan belum optimal sehingga perlu ditingkatkan kualitas dan kuantitas komunikasi agar tujuan dan sasaran kebijakan dapat diterima dengan jelas oleh kelompok sasaran kebijakan.Berkaitan dengan fasilitas yang terbatas maka perlu ditingkatkan jumlah fasilitas yang mendukung pelaksanaan kebijakan izin usaha pengelolaan dan pengusahaan sarang burung walet di Pekanbaru ,Berdasarkan temuan penelitian bahwa jumlah SDM pelaksana kebijakan masih belum optimal maka perlu peningkatan kuantitas dan kualitas SDM pelaksana kebijakan.Anggaran implementasi 
kebijakan izin usaha pengelolaan dan pengusahaan sarang burung walet di Pekanbaru perlu ditingkatkan agar efektifitas implementasi kebijakan dapat lebih optimal, Komitmen pelaksana kebijakan masih kurang sehingga perlu peningkatan komitmen dengan penerapan sanksi tegas bagi pengusaha sarang burung walet yang melanggar aturan.Koordinasi pengawasan izin usaha pengelolaan dan pengusahaan sarang burung walet di Pekanbaru perlu ditingkatkan untuk mengawasi keberadaan lokasi usaha sarang burung walet yang banyak di tengah pemukiman masyarakat.Berdasarkan hasil penelitiaan ditemukan informasi yang menjadi dasar perumusan kebijakan izin usaha pengelolaan dan pengusahaan sarang burung walet di Pekanbaru sudah tidak valid maka perlu dilakukan revisi terhadap kebijakan dimaksud.

\section{Referensi}

Ahlers, A. L., \& Schubert, G, Effective Policy Implementation in China's Local State, Modern China, 2015, 41(4), 372-405.

Aklin, M., Cheng, C. Y., \& Urpelainen, J, Inequality In Policy Implementation: Caste And Electrification In Rural India. Journal of Public Policy, 2020, 129.

Areros, W. A, Aspek Interpretasi Pada Implementasi Kebijakan Pemberian Izin Mendirikan Bangunan Oleh Badan Pelayanan Perizinan Terpadu Kota Manado, Sosiohumaniora, 2013, 15(3), 313-319.

Arief, J. dan I, Implementasi Perda
Pengelolaan Dan Pengusahaan Sarang Burung Walet, Jurnal Demokrasi \& Otonomi Daerah, 2013, 11(1), 43-48.

Bakti, I, Komunikasi Internal Dalam Membangun Kohesivitas Kelompok Pegiat Wisata Di Kabupaten Pangandaran. Sosiohumaniora, 2020, 22(1), 46-54.

Budd, E. L., Schwarz, C., Yount, B. W., \& Haire-Joshu, D, Factors Influencing The Implementation of School Wellness Policies In The United States, 2009. Preventing Chronic Disease, 2012, 9(6), 1-9.

Coleman, A., Billings, J., Allen, P., Mikelyte, R., Croke, S., MacInnes, J., \& Checkland, K, Ambiguity And Conflict In Policy Implementation: The Case Of The New Care Models (Vanguard) Programme In England, Journal of Social Policy, 2020, 1-20.

Cormac, I., \& McNally, L, How To Implement A Smoke-Free Polic, Advances in Psychiatric Treatment, 2008, 14(3), 198207.

Deng, Y., O'Brien, K. J., \& Chen, J, Enthusiastic Policy Implementation and its Aftermath: The Sudden Expansion and Contraction of China's Microfinance for Women Programme, China Quarterly, 2018, 234, 506-526.

Elsye, R, Implementasi Kebijakan Desentralisasi Fiskal Di Provinsi Sumatera Selatan, Sosiohumaniora, 2014, 16(2), 171. 
Eny Susilowati, Pengaturan Terhadap Pembangunan Gedung Sarang Burung Walet Di Kota Palangka Raya Provinsi Kalimantan Tengah, Morality: Jurnal Ilmu Hukum, 2018, 4(1).

Giest, S, Making Energy Personal: Policy Coordination Challenges In UK Smart Meter Implementation, Journal of Public Policy, 2019, 120.

Hardiyansyah, H., \& Effendi, R, Model Implementasi Kebijakan Publik dalam Pengelolaan Sampah dan Kebersihan Kota Palembang, MIMBAR, Jurnal Sosial Dan Pembangunan, 2014, Vol. 30, p. 108.

Joniarta, I. W., Sucitawathi P, I. G. A. A. D., Soares, I., \& Suderana, W, Studi Implementasi Kebijakan Desentralisasi Administratif Di Municipio Dili Timor-Leste, Politika: Jurnal Ilmu Politik, 2019, 10(1), 40.

Kostka, G., \& Hobbs, W, Local Energy Efficiency Policy Implementation In China: Bridging The Gap Between National Priorities And Local Interests, China Quarterly, 2012, 211(211), 765-785.

Kurniawan, $\quad \mathrm{B}, \quad$ Implementasi Kebijakan Sertifikasi Guru Dalam Rangka Meningkatkan Profesionalitas Guru Di Kota Yogyakarta, Journal of Government and Politics, 2011, 2(2), 259-278.

Lambelanova, R, The Policy Implementation of Autonomy Area the Fields of Education,
Health and Economy in West Bandung District, Sosiohumaniora, 2017, 19(2), 185-198.

Liévanos, R. S, Certainty, Fairness, and Balance: State Resonance and Environmental Justice Policy Implementation, Sociological Forum, 2012, 27(2), 481-503.

Loft, L., Pham, T. T., Wong, G. Y., Brockhaus, M., Le, D. N., Tjajadi, J. S., \& Luttrell, C, Risks to REDD+: Potential Pitfalls For Policy Design And Implementation, Environmental Conservation, 2017, 44(1), 44-55.

Manojlovich, M., Squires, J. E., Davies, B., \& Graham, I. D, Hiding In Plain Sight: Communication Theory In Implementation Science, Implementation Science, 2015, 10(1), 1-11.

Marquardt, J, How Power Affects Policy Implementation: Lessons From The Philippines, Journal of Current Southeast Asian Affairs, 2017,36(1), 3-27.

McAvoy, B. R., \& Yallop, J. J, Implementing A Smoke-Free Policy In An Inpatient Withdrawal Unit. Journal of Smoking Cessation, 2013, 9(2), 119-121.

Medie, P. A., \& Walsh, S. D. International Organizations, Nongovernmental Organizations, and Police Implementation of Domestic Violence Policies in Liberia and Nicaragua, Politics and Gender, 2019, 1-31.

Mueller, D. Addressing The Challenges 
Of Implementing A Health Technology Assessment Policy Framework In South Africa, International Journal of Technology Assessment in Health Care, 2020, (7), 1-6.

Nunes, J., \& Lotta, G, Discretion, Power And The Reproduction of Inequality In Health Policy Implementation: Practices, Discursive Styles And Classifications of Brazil's Community Health Workers, Social Science and Medicine, 2019, 242(January), 112551.

Pradipta, A., Amin, M., Sumpala, A. T., \& Sutoyo, M. N, Sistem Pendukung Keputusan Menentukan Lokasi Rumah Burung Walet (RBW) Menggunakan Metode AHP dan $S A W$, Jurnal Sains Dan Informatika, 2019, 5(2), 157.

Putera, R. E, Implementasi Kebijakan Otonomi Daerah Bidang Pendidikan Dalam Pencapaian Millennium Development Goals (MDGs) di Kota Padang, MIMBAR, Jurnal Sosial Dan Pembangunan, 2015, 31(1), 229.

Rahmawati, R., Hernawan, D., Darusman, D., \& Sektiono, D, Kinerja Implementasi Tata Kelola Hutan Taman Nasional Gunung Halimun Salak, Sosiohumaniora, 2019, 21(3), 305-315.

Ramadani, Mardiyono, E, Implementasi Kebijakan Satu Peta Energi Sumber Daya Mineral (Esdm One Map) di Kementerian Energi Sumber Daya Mineral Republik Indonesia, Matra Pembaruan, 2019, 3(2), 109-
118.

Sasbudiarta, S, Dampak Industri Sarang Burung Walet Terhadap Perubahan Sosial Ekonomi Masyarakat Di Dusun Tunggun Desa Tunggunjagir Kecamatan Mantup Kabupaten Lamongan, Swara Bhumi, 2018, 5(8).

Sjoraida, D. F, Implementasi Kebijakan Keterbukaan Informasi Publik Pada Pemerintah Provinsi Jawa Barat, Sosiohumaniora, 2015, 17(3), 204.

Sugiyono, 2011, Metode Penelitian Kuantitatif, Kualitatif dan $R \& D$, Bandung: Penerbit Alfabeta.

Sulastiyo, D., Kartodihardjo, H., \& Soedomo, S, The Effectiveness of Policy Implementation on Forest Rehabilitation and Reclamation, Jurnal Silvikultur Tropika, 2016, 07(3), 181-187.

Suyatna, U, Implementasi Kebijakan Ekspor Di Indonesia, Jurnal IlmuIlmu Sosial Dan Humaniora, 2019, 21(2), 173-183.

Tummers, L., \& Bekkers, V, Policy Implementation, Street-level Bureaucracy, and the Importance of Discretion, Public Management Review, 2014, 16(4), 527-547.

Zhan, X., Wing-Hung Lo, C., \& Tang, S. $\mathrm{Y}$, Contextual changes and environmental policy implementation: A longitudinal study of street-level bureaucrats in Guangzhou, China, Journal of Public Administration Research and Theory, 2014, 24 